В. О. Подліпаєв

Інститут телекомунікацій і глобального інформаційного простору НАН України, Київ, Україна

\title{
БАЗОВИЙ НАБІР ТИПОВИХ ГЕОІНФОРМАЦЙНИХ РЕСУРСІВ ДЛЯ ЗДІЙСНЕННЯ ГЕОІНФОРМАЦЙНОЇ ПІДТРИМКИ ТА ВЕДЕННЯ ГЕОПРОСТОРОВОГО АНАЛІЗУ
}

\begin{abstract}
Предметом вивчення в статті $є$ необхідно достатній функціонал роботи з геопросторовими даними. Метою $є$ визначення переліку та загального функціоналу геоінформаційних ресурсів для здійснення геоінформаційної підтримки та ведення геопросторового аналізу. Завдання: визначити базовій набір геоінформаційних ресурсів який $є$ мінімально необхідним для забезпечення геоінформаційної підтримки та ведення геопросторового аналізу; визначити загальний функціонал типових геоінформаційних ресурсів базового набору, який необхідний для забезпечення геоінформаційної підтримки та ведення геопросторового аналізу. Використовуваними методами є: методи статистичного аналізу, методи оптимізації, методи моделювання, методи побудови складних систем Отримані такі результати. Встановлено, що актуальним $є$ питання створення такого набору геоінформаційних ресурсів, який би на мінімально достатньому рівні задовольняв потреби у геоінформаційній підтримці та забезпечив максимальну ефективність побудованої геоінформаційної системи. Встановлено, що існує геоінформаційні ресурсі, які затребувані у бідь-якій сфері діяльності, а їх функціонал роботи з геопросторовими даними від неї не залежить. Визначено наступний базовий набір типових геоінформаційних ресурсів: геоінформаційні ресурси, які призначені для збору, систематизації та накопичення базового набору геопросторових даних; геоінформаційні ресурси, які призначені для збору, систематизації, накопичення та відображення геопросторових даних та іншої інформації про об'єкти, які розташовані на певній території (акваторії); геоінформаційні ресурси, які призначені для відображення оперативної інформації (новини, події, розвідувальні дані, тощо) на визначній карті з прив'язкою до місцевості або об'єкту, яких стосується ця інформація. Також, визначено загальний функціонал цих ресурсів. Висновки. Визначений базовий набір типових геоінформаційних ресурсів охоплює всі основні питання геоінформаційної підтримки та геопросторового аналізу. Такий підхід надає змогу, за умов можливості, необхідності та достатності отримання даних, мати оперативну поінформованість де?, що? і коли? відбувається і відбувалось та найповнішу інформацію про потрібні території та об'єкти на них. Можливість цих базових типових геоінформаційних ресурсів використовувати інформацію з баз даних, які не входять до складу ГІС і супроводжуються окремо або у складі інших інформаційних систем, унеможливлює дублювання цієї інформації та значно спрощує структуру власних баз даних ГІС.
\end{abstract}

Кл юч ов і сл ов а : геоінформаційна підтримка, геоінформаційна система, геоінформаційні ресурси, геопросторовий аналіз, геопросторова інформація, геопросторові дані.

\section{Вступ}

Система геоінформаційної підтримки призначення для забезпечення органів управління, інформаційно-аналітичних та інших підрозділів необхідними геопросторовими даними, надання їм можливості обмінюватися цими даними та використовувати спеціалізовані геоінформаційні ресурси для збору та накопичення власної інформації, яку вони використовують при виконанні завдань за призначенням.

Фізично, система геоінформаційної підтримки являє собою геоінформаційну систему, яка повинна складатися з наступних обов'язкових елементів:

технічні засоби;

програмне забезпечення;

дані, як циркулюють в системі;

методи і алгоритми роботи 3 цими даними;

люди (персонал підтримання функціонування системи, користувачі та інші).

Геоінформаиійна система (ГІС) - система апаратно-програмних засобів і алгоритмічних процедур, що створена для цифрової підтримки, поповнення, управління, маніпулювання, аналізу, математико-картографічного моделювання і образного відображення географічно координованих (визначених) даних [1,2].

Технічні засоби та програмне забезпечення базові складові, які не визначають спрямованість
ГІС, а лише забезпечують іï потужності щодо роботи $з$ геопросторовими даними.

Дані, які циркулюють в системі - $є$ змістовною складовою ГІС.

Методи і алгоритми роботи 3 цими даними профільна складова, які саме і визначають спрямованість ГІС.

Виходячи зі світового досвіду та враховуючі стандарти НАТО геоінформаційну систему доцільно побудувати на базі серійних комп'ютерів і серверів об'єднаних в мережу, у якій розгорнуто геопортал за допомогою спеціалізованого програмного забезпечення.

Геопортал - сукупність окремих додатків і сервісів, які використовуються для публікації, адміністрування та пошуку необхідних геоінформаційних ресурсів [2].

Пошук, візуалізація, використання, накопичення, зберігання, обмін даними між користувачами геоінформаційної системи повинен здійснюватися за допомогою геоінформаційних ресурсів, в яких реалізовані всі необхідні методи та алгоритми роботи 3 цими даними.

Геоінформаційний ресурс - сукупність інформаційних банків і баз геопросторових даних, метаданих і сервісів геопросторових даних [1,2]. Саме цей момент у побудові геоінформаційної системи $\epsilon$ найбільш складний точки зору її ефективності. 
Аналіз літературних даних та постановка проблеми. За останні роки у світі, та в Україні зокрема, накопичено значний досвід щодо створення спеціалізованих геоінформаційних систем. 3 кожним роком з'являються все нові підходи до організації геоінформаційної підтримки та побудови геоінформаційних систем.

В рамках досліджень було проведено вивчення доступної літератури і зразків відомих геоінформаційних систем та аналіз їх можливостей [3-14]. За результатами роботи можна зазначити певну сталу особливість, а саме: - основною, чи не єдиною, відмінністю всіх ГІС є їх геоінформаційні ресурси. Саме вони є визначальними, а інші складові системи лише забезпечують їх роботу.

Наявність в системі найпотужніших технічних засобів та найсучаснішого програмного забезпечення не виконує головної задачі ГІС, а лише забезпечує потужності іiі виконання. Механізми виконання основних завдань ГІС реалізуються через методи та алгоритми роботи 3 даними, які знаходяться у системі. Але, щоб все це функціонувало треба чітко визначити, які дані нам необхідно завантажувати у систему, і яких спеціалістів необхідно залучити.

Правильно визначений склад та побудова геоінформаційних ресурсів забезпечує ефективність геоінформаційної системи.

На сьогоднішній день, на жаль, геоінформаційний ринок в Україні не надто розвинений. Це інноваційний напрямок, який все ще набуває популярності, в той час, як у розвинених країнах він повсякчас застосовується у найрізноманітніших сферах. Таке становище спричинене в першу чергу двома факторами: недостатньою поінформованістю суспільства про можливості та переваги ГІС, а також відсутністю коштів для впровадження подібних систем на тлі поточної економічної ситуації в країні. І якщо вирішення першої перепони - це лише питання часу, то друга ховає в собі підводні камені, які не одразу помітні [14].

Затрати на збір, систематизацію, обробку, накопичення та зберігання геопросторових даних повинні бути максимально компенсовані за рахунок затребуваності цих даних та результатів їх аналізу.

Тому, розробляючи геоінформаційну систему, чітко потрібно усвідомити, яке вона має призначення та які основні функції повинна виконувати. Якщо у ході експлуатації виникне потреба у додатковому функціоналі, його завжди можна нарости, а створений але не затребуваний ресурс - це вже зайве витрачені гроші.

Досвід показує, що використання ГІС здійснюється в основному за двома варіантами. У першому - ГІС виконує функції довідкової системи, яка забезпечує можливість користувачів отримати необхідні геопросторові дані. У другому - ГІС виконує функції геоінформаційної платформи, на якій можна вирішувати різноманітні інформаційні завдання, у тому числі з використанням не тільки геопросторових даних, а і іншої інформації.

Крім того, використання ГІС, за обома варіантами, здійснюється у таких режимах: отримання необхідних даних, яке здійснюється шляхом їх візуалізації на персональних і колективних засобах відображення або копіювання на електронні та тверді носії інформації;

завантаження геопросторової та іншої інформації до відповідних баз даних, з метою оновлення наявної в системі інформації та збільшення інформаційних можливостей самої ГІС;

накопичення та зберігання користувачем власної інформації, а також створення ним інформаційних ресурсів;

обмін інформацією між користувачами ГІС.

Можливості сучасних ГІС дуже великі, а з розвитком програмного забезпечення і технічних засобів постійно нарощуються. Та і вибагливість сучасних користувачів змушує розробників ГІС постійно розширювати набір функцій цих систем.

Однак, це загальні тенденції, а побудова конкретної ГІС - це окреме питання, при вирішенні якого потрібно врахувати насамперед вимоги, які висуваються саме до цієї конкретної системи. Безумовно, беручі до уваги досвід побудови та використання існуючих систем та сучасні тенденції розвитку ГІС в цілому.

Як зазначалось вище, особливістю кожної ГІС є iii геоінформаційні ресурси, тому виникає актуальне питання, - “Які геоінформаційні ресурси необхідно створити?".

Мета та задачі дослідження. Метою дослідження є визначення переліку та загального функціоналу геоінформаційних ресурсів для здійснення геоінформаційної підтримки та ведення геопросторового аналізу.

Для досягнення поставленої цілі необхідно вирішити наступні задачі:

- визначити базовій набір типових геоінформаційних ресурсів який $є$ мінімально необхідним для забезпечення геоінформаційної підтримки та ведення геопросторового аналізу;

- визначити загальний функціонал типових геоінформаційних ресурсів базового набору, який необхідний для забезпечення геоінформаційної підтримки та ведення геопросторового аналізу.

\section{1. Матеріали дослідження щодо визначення базового набору типових геоінформаційних ресурсів}

Сучасні ГІС мають різні рівні складності, від простих інформаційних систем до складних аналітичних 3 автоматизованими (автоматичними) алгоритмами підготовки (прийняття) рішень. Від рівня складності змінюється набір функцій, які може виконувати система, але, основне іiі призначення залишається незмінним - своєчасне надання потрібної інформації.

Саме ці два критерії - своєчасність надання інформації і її потрібність, є основними регуляторами створення архітектури ГІС, формування її інформаційного змісту, а також побудови алгоритмів збору та надання інформації споживачам.

Бажання ідеально визначити виключний перелік геоінформаційних ресурсів та спроектувати їх 
архітектуру, не переходячи при цьому в практичну площину, значно збільшує ризики залишити питання побудови потрібної ГІС на стадії вічного пошуку ідеального рішення.

Геоінформаційні технології - це сфера науки і техніки, яка постійно розвивається, та у якій нерідко з'являються дуже прогресивні рішення, причому спрогнозувати їх дуже складно. Тому закладавати, у складі ГІС ресурси, використання яких планується не одразу, а через деякий час, недоцільно. Це призведе до того, коли прийде час використовувати ці ресурси, технології, на яких вони були розроблені, вже застаріли та менш ефективні.

Вирішити це питання можливо, шляхом розробки, на першому етапі створення ГІС, загальних (базових) геоінформаційних ресурсів, без яких геоінформаційна підтримка не можлива. Кількість цих ресурсів та їх фунціонал, спочатку можуть бути не значними, але це дозволить уникнути зайвих витрат та більш ефективно розвивати побудовану ГІС у подальшому, враховуючі зростання та зміни вимог користувачів, а також світові тенденції розвиту геоінформаційних технологій.

Проектування та розгортання в ГІС базового набору типових геоінформаційних ресурсів наддасть змогу найбільш ефективно вирішити порушене питання. Цей набір є мінімально достатнім, а значить найбільш приближеним до ефективного.

Достатність повинна забезпечуватись наявністю такого набору геоінформаційних ресурсів та їх функціоналу, збільшення якого вже починає призводити до того, коли витрати на додатково розроблені ресурси та створені функції стають більш значними ніж нові можливості, які з'явились в системі.

Будь-якого керівника та аналітика цікавить “що?”, “де?”, “коли?” відбувалось, відбувається та відбудиться, тому геоінформаційні ресурси ГІС повинні допомагати знайти відповіді на ці питання.

Різні сфери діяльності та рівень, важність і актуальність питанні, які викрашуються керівниками та аналітиками у цих сферах, мають особливості щодо їх геоінформаційної підтримки іiі спрямованості та змісту і обсягу необхідних геопросторових даних. Відповідно й ведення гепросторового аналізу, як однієї із функціональних складових геоінформаційної підтримки, потребує чітко виражені вимоги до цих даних та алгоритмів і методів роботи з ними.

Геоінформаційна підтримка у сфері національній безпеки і оборони, у сфері виробництва, управління територіями, в екологічній сфері та інших сферах потребує розробки спеціалізованих геоінформаційних систем з притаманними саме цим сферам геоінформаційними ресурсами. У якості прикладу наведемо вимоги до змісту геопросторових даних, які висувають військові США при забезпеченні геопросторової підтримки у ході планування та проведення об'єднаних операцій. (рис. 1).

Відповідно до призначення ГІС та визначеного змісту і обсягу геопросторових даних необхідно розробити геоінформаційні ресурси потрібні забезпеченні геоінформаційної підтримки певної сфери діяльності або кола питань, які вирішуються. Однак, якби сфери діяльності не відрізнялись, які б вони не мали особливості, є геопросторової дані та алгоритми роботи з ними, які скрізь однакові. Більш того, фунціонал роботи з цими даними взагалі не залежить від сфери, для якої ці дані вирисовуються. Все це і являє собою основу так званого універсального набору геоінформаційних ресурсів, якій і $є$ базовим.

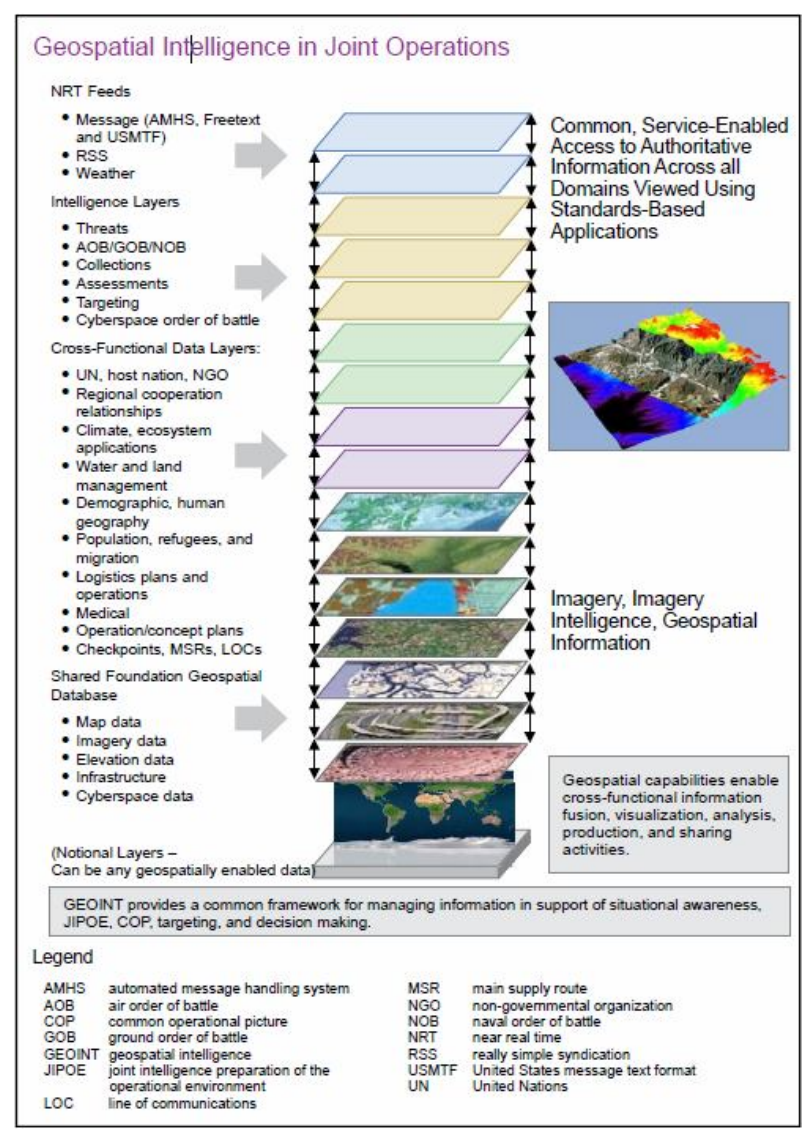

Рис. 1. Набір геопросторих даних, якій обробляється геопросторовою розвідкою США, для здійснення геоінформаційної підтримки об'єднаних операцій

Без даних про території геоінформаційна підтримка не можлива в принципі. А які саме дані потрібні, це вже питання необхідності та достатності цих даних. Тому геоінформаційні ресурси, які забезпечують надання інформації про території (базового набору геопросторових даних) є обов'язковим типом ресурсів для будь-якої ГІС.

Базові геопросторові дані - сукупність загальнодоступних стандартизованих геопросторових даних як уніфікованої основи для інтегрування та спільного використання в геоінформаційних системах геопросторових даних [1]. Основним об'єктом геопросторового аналізу є геопросторові об'єкти, тому інструментарій для отримання, а бажано накопичення та аналізу, інформації про ці об'єкти є необхідним.

Геопросторовий об 'єкт - об'єкт реального світу та суспільно-економічних відносин, що характеризується певним місцезнаходженням на Землі i визначений у встановленій системі просторовочасових координат [1].

Крім використання даних про фізичні об'єкти аналітик обробляє дуже великий обсяг інформації 
про події та явища. Так, як події та явища завжди відбуваються десь (територія, акваторія, об'єкт) або мають до них відношення, тому необхідність зазначених вище типів геоінформаційних ресурсів значно підвищується.

3 метою підвищення оперативності поінформованості споживача про те, де мають місце певні події та явища, доцільно у складі ГІС мати геоінформаційні ресурсі відображення оперативної інформації про події та явища з прив'язкою їх до території (акваторії) або об'єкту, до яких вони мають відношення.

Підсумовуючи вище зазначене можна визначити наступний базовий набір типових геоінформаційних ресурсів:

геоінформаційні ресурси, які призначені для збору, систематизації та накопичення базового набору геопросторових даних;

геоінформаційні ресурси, які призначені для збору, систематизації, накопичення та відображення геопросторових даних та іншої інформації про об'єкти, які розташовані на певній території (акваторіі);

геоінформаційні ресурси, які призначені для відображення оперативної інформації (новини, події, розвідувальні дані, тощо) на визначній карті з прив'язкою до місцевості або об'єкту, яких стосується ця інформація.

\section{2. Визначення загального функціоналу типових геоінформаційних ресурсів базового набору}

2. 1. Геоінформаційні ресурси, які призначені для збору, систематизації та накопичення базового набору геопросторових даних (рис. 2). Ці ресурси повинні містити наступні данні та мати сервіси:

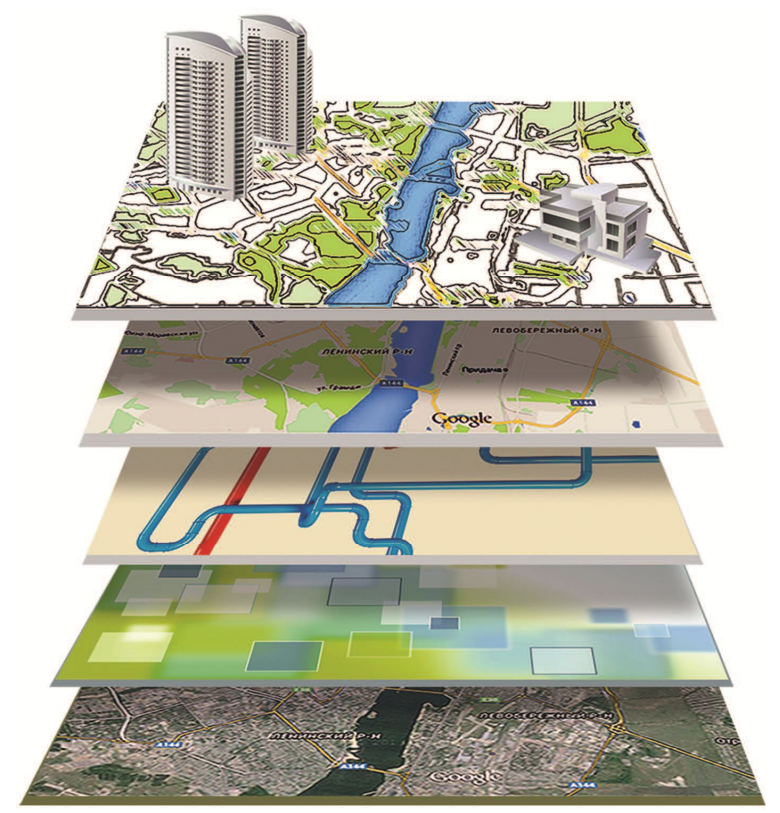

Рис. 2. Приклад базового набору геопросторових даних

архіви матеріалів аерокосмічної зйомки земної поверхні з можливістю їх ретроспективного перегляду та порівнянням обраних матеріалів;

картографічні матеріали визначених масштабів у растровому і векторному форматах з можливість використання окремих шарів даних (шляхи, елементи забудови тощо);

назви населених пунктів та межі адміністративних одиниць різного рівня з їх назвами;

визначені гібридні (інтеграція матеріалів зйомки і картографічних матеріалів) базові карти 3 можливість додавати та вилучати певні шари даних, а також створювання нових карт.

пошук необхідних даних за визначеними критеріями (назва адміністративної одиниці, населеного пункту, штучного або природнього об'єкту, координати тощо).

2. 2. Геоінформаційні ресурси, які призначені для збору, систематизації, накопичення та відображення геопросторових даних та іншої інформації про об'скти, які розташовані на певній території (акваторії) (рис. 3). Ці ресурси повинні містити наступні дані та мати сервіси:

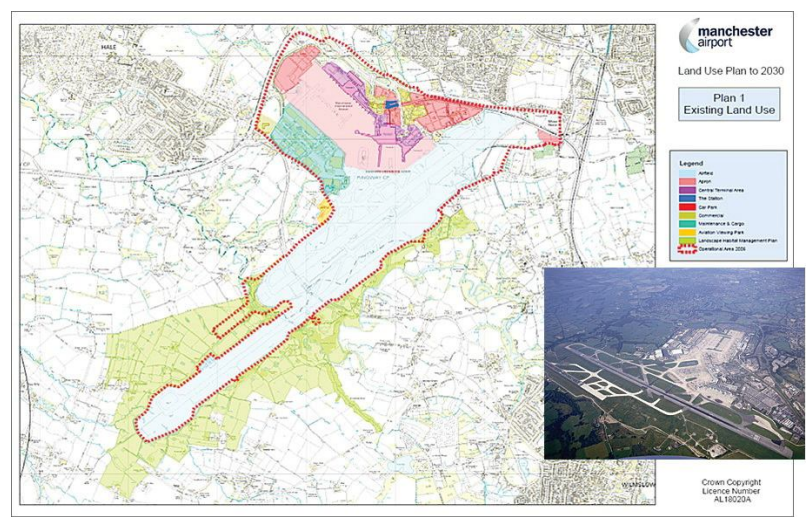

Рис. 3. Приклад геоінформаційного ресурсу накопичення та роботи з інформацією про об'єкти

набір умовних знаків різних типів об'єктів (об'єкти інфраструктури, військові об'єкти, об'єкти промисловості та інших сфер діяльності країни тощо) 3 можливістю їх нанесення на карту, а у разі відсутності необхідного знаку, створення нового;

при позначені обраного об'єкту певним умовним знаком, створюється інформаційний шар, таблиця якого має мінімально необхідний набір полів для накопичення даних про об’єкт обраного типу (для аеродромів свій набор полів, для складів свій, для військових містечок свій) 3 можливість додавання нових полів до цієї таблиці та створення нової таблиці з власним набором полів;

створення інформаційних шарів для позначення простих об'єктів, таких як технічні засоби (озброєння та військова техніка), елементи обладнання території (будівлі, майданчики, мости тощо) та інші об'єкти, а також групи інформаційних шарів для позначення складних об'єктів, таких як аеродроми, порти, різни полігони та склади, підприємства та електростанції тощо;

відображення геопросторових даних та іншої інформації, які у будь якій мірі стосуються обраного об'єкту, але зберігаються в інших інформаційних базах даних.

2.3. Геоінформаційні ресурси, які призначені для відображення оперативної інформації (розвідувальні дані, події, новини, тощо) на визначній 
карті з прив'язкою до місцевості або об'скту, яких стосусться ця інформація (рис. 4). Ці ресурси повинні містити наступні дані та мати сервіси:

відображення на карті визначеними умовними знаками оперативної інформації;

відображення змістовної частини оперативної інформації у певній послідовності вишикуваної за визначними критеріями (за датою та часом, місцем події, об'єктом, тематикою рівнем важливості інформації тощо);

відображення відповідної оперативної інформації у інших геоінформаційних ресурсах та іiі завантаження до інших баз даних;

архів оперативної інформації з можливістю пошуку необхідної інформації за визначними критеріями (за датою та часом, місцем події, об'єктом, тематикою тощо).

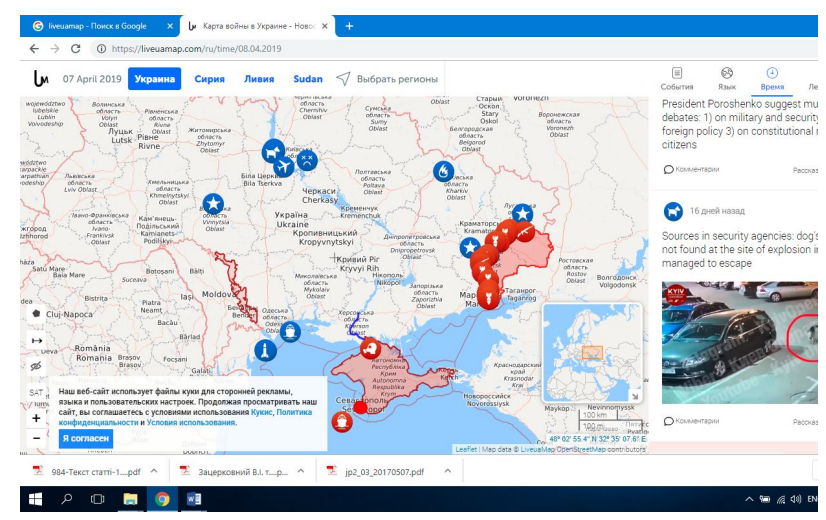

Рис. 4. Приклад геоінформаційного ресурсу інтерактивного відображення подій, які відбуваються на певній території

\section{Висновки}

Визначено базовій набір геоінформаційних ресурсів. Визначено загальний функціонал типових геоінформаційних ресурсів. Ці ресурси $є$ типовим саме тому, що їх може бути декілька, в залежності від алгоритмів і методик роботи з геопросторовими даними, які реалізовані в конкретній ГІС. Обов'язковою умовою є пов'язаність цих типових ресурсів та наявних в них даних притаманних тільки цьому типу. Це значить, якщо карти завантажуються та систематизуються за допомогою геоінформаційного ресурсу, який призначеній для ведення базового набору геопросторових даних, то вони також доступні споживачу через інші геоінформаційні ресурси без копіювання. Теж повинно бути $з$ даними про об'єкти, події та явища, інформація завантажується до бази даних один раз за допомогою відповідного інструментарію та може бути використана у будь-якому геоінформаційну ресурсі без копіювання або перенесення.

Ці три типи геоінформаційних ресурсів охоплюють всі основні питання геоінформаційної підтримки та геопросторового аналізу, а функціонал та кількість ресурсів кожного типу є вже питанням нарощування потужності ГІС. (рис. 5)

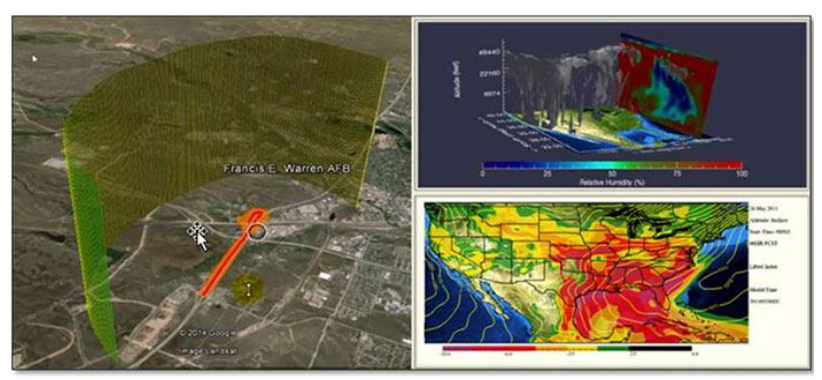

Рис. 5. Приклади деяких напрямків ведення геопросторового аналізу

Такий підхід надає змогу, за умов можливості, необхідності та достатності отримання даних, мати оперативну поінформованість де?, що? і коли? відбувається і відбувалось та найповнішу інформацію про потрібні території та об'єкти на них.

Можливість цих базових типових геоінформаційних ресурсів використовувати інформацію з баз даних, які не входять до складу ГІС і супроводжуються окремо або у складі інших інформаційних систем, унеможливлює дублювання цієї інформації та значно спрощує структуру власних баз даних ГІС.

\section{СПИСОК ЛІТЕРАТУРИ}

1. Проект закону України "Про національну інфраструктуру геопросторових даних".

2. “Воєнна розвідка. Геопросторова розвідка. Терміни та визначення”, Військовий стандарт 01.101.007 Видання 1, ВСТ 01.101.007-2017(01).

3. .Geospatial Intelligence in Joint Operations // Joint Publication 2-03 - 5 July 2017.

4. AIRBUS Multi-Int, https://www.intelligence-airbusds.com/en/8207-defence-security.

5. GIS for Defense, https://www.esri.com/en-us/industries/government/ departments/defense.

6. GIS for Defense, http://www.esriuk.com/Development/Industries/defence.

7. What is GIS?, https://www.esri.com/en-us/what-is-gis/overview.

8. Кохан, С. С. Розроблення структури бази знань системи геоінформаційного моніторингу для оцінювання якісного стану земель сільськогосподарського призначення / С. С. Кохан, А. А. Москаленко // Східно-Свропейський журнал передових технологій. - 2015. - № 5/2 (77). - С. 32-37.

9. Kuchuk G., Nechausov S., Kharchenko, V. Two-stage optimization of resource allocation for hybrid cloud data store. International Conference on Information and Digital Technologies. 2015. P. 266-271. DOI: http://dx.doi.org/10.1109/DT.2015.7222982

10. Бутко М.П., Теорія прийняття рішень / книга, ЦУЛ - 2018, с. 360.

11. Коваленко А.А. Сучасний стан та тенденції розвитку комп'ютерних систем об'єктів критичного застосування / А.А. Коваленко, Г.А. Кучук // Системи управління, навігації та зв'язку. - Полтава . ПНТУ, 2018. - Вип. 1(47). - С. 110-113.

12. Геоінформаційні системи. Створення та впровадження аналітичних систем на базі цифрових карт / сайт Державно науково-виробничого підприємства “Картографія”, http://ukrmap.com.ua/e-maps/geoinformatsijni-sistemi/

13. Ищук А.А., Серединин Є.С., Карпенко С.А., Мельник А.В. Геоинформационные системы в Украине: основные тенденции и проблемы развития. Ученые записки ТНУ. Серия “География”. тТом. 23 (62), 2010. № 2. С. 13-21. 
14. Федорієнко В. А.; Головченко О. В.; Васюхно С. І. Особливості сучасної концептуальної архітектури ГІС платформи військового призначення. 2017.

15. Серединін С., Липський В., Філозоф Р., Розробка та активне використання геоінформаційних систем, часопис РЕГІОНЕТ "Стратегія розвитку" №4, липень 2017, http://regionet.org.ua/ua/Rozrobka ta aktuvne vukorustannya geoinformatsiynuh_sustem_GIS_2632633.html\#page title

Рецензент: д-р техн. наук, проф. С. В. Козелков, Державний університет телекомунікацій, Київ

Received (Надійшла) 12.02.2019

Accepted for publication (Прийнята до друку) 27.03.2018

\title{
Базовый набор типовых геоинформационных ресурсов для осуществления геоинформационной поддержки и ведения геопространственного анализа
}

\author{
В. А. Подлипаев
}

Предметом изучения в статье является необходимо достаточный функционал работы с геопространственными данными. Целью является определение перечня и общего функционала геоинформационных ресурсов для осуществления геоинформационной поддержки и ведения геопространственного анализа. Задачи: определить базовой набор геоинформационных ресурсов который является минимально необходимым для обеспечения геоинформационной поддержки и ведения геопространственного анализа; определить общий функционал типовых геоинформационных ресурсов базового набора, который необходим для обеспечения геоинформационной поддержки и ведения геопространственного анализа. Используемые методы: методы статистического анализа, методы оптимизации, методы моделирования, методы построения сложных систем. Получены такие результаты. Установлено, что актуальным является вопрос создание такого набора геоинформационных ресурсов, который бы на минимально достаточном уровне удовлетворял потребности в геоинформационной поддержке и обеспечил максимальную эффективность построенной геоинформационной системы. Установлено, что существует геоинформационные ресурсе, которые востребованы в любой сфере деятельности, а их функционал работы с геопространственными данными от нее не зависит. Определено следующий базовый набор типовых геоинформационных ресурсов: геоинформационные ресурсы, которые предназначены для сбора, систематизации и накопления базового набора геопространственных данных; геоинформационные ресурсы, которые предназначены для сбора, систематизации, накопления и отображения геопространственных данных и другой информации об объектах, расположенных на определенной территории (акватории) геоинформационные ресурсы, которые предназначены для отражения оперативной информации (новости, события, разведывательные данные и т.д.) выдающуюся карте с привязкой к местности или объекта, которых касается эта информация. Также, определен общий функционал этих ресурсов. Выводы. Определенный базовый набор типовых геоинформационных ресурсов охватывает все основные вопросы геоинформационной поддержки и геопространственного анализа. Такой подход дает возможность, в условиях возможности, необходимости и достаточности получения данных, иметь оперативную осведомленность где?, что? и когда? происходит и происходило и полную информацию о нужных территории и объекты на них. Возможность этих базовых типовых геоинформационных ресурсов использовать информацию из баз данных, которые не входят в состав ГИС и сопровождаются отдельно или в составе других информационных систем, делает невозможным дублирование этой информации и значительно упрощает структуру собственных баз данных ГИС.

Ключевые слова: геоинформационная поддержка, геоинформационная система, геоинформационные ресурсы, геопространственный анализ, геопространственная информация, пространственные данные.

\section{Basic set of typical geoinformation resources for the implementation of geoinformation support and processing of geoprostoral analysis V. Podlipaiev}

The subject matter of the article is the need for a sufficient functional of work with geospatial data. The goal is to determine the list and general functional of geographic information resources for geoinformational support and geospatial analysis. The tasks are: to define the basic set of geographic information resources which is the minimum necessary for providing geoinformational support and conducting geospatial analysis; determine the general functional type of geographic information resources of the base set, which is necessary for providing geoinformation support and conducting geospatial analysis. The methods used are: statistical analysis methods, optimization methods, methods of modulation, methods of constructing complex systems. Such results are obtained. It is established that the issue of creation of such a set of geographic information resources that would satisfy the needs of geoinformation support at the least sufficient level and ensure the maximum effectiveness of the built geographic information system is relevant. It is established that there are geoinformation resources that are in demand in some area of activity, and their function of work with geospatial data from it does not depend on it. Determine the following basic set of typical geographic information resources: geoinformation resources, which are intended to collect, systematize and accumulate the basic set of geospatial data; geoinformational res-psi, which are intended for the collection, systematization, accumulation and display of geospatial data and other information about objects located in a certain territory (waters); geoinformation resources that are intended to display operational information (news, events, intelligence, etc.) on a map of the reference to the locality or object to which this information relates. Also, the overall functionality of these resources is determined. Conclusions. The identified basic set of typical geoinformation resources covers all major issues of geoinformation support and geospatial analysis. This approach enables, in the event of the possibility, the need and the sufficiency of obtaining data, to have an operational awareness of where? And when? the most complete information about the necessary territories and objects on them has taken place and took place. The ability of these basic reference geographic information resources to use information from databases that are not part of GIS and are either individually or in combination with other information systems prevents duplication of this information and greatly simplifies the structure of its own GIS databases.

Keywords: geoinformation support, geoinformation system, geoinformation resources, geospatial analysis, geospatial information, geospatial data. 